\title{
Inheritance of Hermaphrodite (Khuntha) under the Muslim Law: An Overview
}

\author{
Mohi Uddin \\ Department of Law, International Islamic University Chittagong, Chittagong, Bangladesh \\ Email:adv.mohim@gamil.com
}

How to cite this paper: Uddin, M. (2017) Inheritance of Hermaphrodite (Khuntha) under the Muslim Law: An Overview. Beijing Law Review, 8, 226-237. https://doi.org/10.4236/blr.2017.82013

Received: April 28, 2017

Accepted: June 27, 2017

Published: June 30, 2017

Copyright $\odot 2017$ by author and Scientific Research Publishing Inc. This work is licensed under the Creative Commons Attribution International License (CC BY 4.0).

http://creativecommons.org/licenses/by/4.0/

\section{(c) (i) Open Access}

\begin{abstract}
Like other creation of almighty Allah, the hermaphrodite should also be treated as human being and if we treated them as human they must have some rights, liabilities etc. This research shall try to explain and show one of their basic rights that mean the rights of inheritance. Quran does not speak about their rights of inheritance. So Jurists derive some rules about their right of inheritance with the help of Hadith and Qiyas. As there is a gap between religion and society, our society does not protect them and does not give their rights. So it is needed to protect them and make them strong financially they can also get their rights, respect, honor and care from society. This article shall also try to give an overview on the inheritance of hermaphrodite under the spirit of Quran with the help of Hadith, Qiyas and different opinions of the Imam and jurists. Finally, in this research, the researcher shall try to make sure a framework for the deprive hermaphrodite in Muslim countries in compliance with the mentioned provisions of Holy Quran, Hadith, Ijma, Qiyas, and also opinion of different eminent jurists of the Muslim World.
\end{abstract}

\section{Keywords}

Hermaphrodite, Inheritance, Khuntha, Khuntha Muskila, Deceased

\section{Introduction}

The Islamic Law of inheritance has been given by Allah (SWT) in judicious and continuing manner and in accordance with the human nature. At initial stages Islam approved the inheritance of Zahaliya, a provisional system based on kinship and hijra. Then the system was domineered with the system of wassiyat. ${ }^{1}$ At the final stage of Islam, verses of the Quran given to us by Allah (SWT) are 11,

${ }^{1}$ Prof. Ridzuan M. Awang, "The Islamic Inheritance Law (faraid), The Manifestation of Comprehensive Inheritance Management in Islam, Islamic Law (shariah)” Dept, University Kabangsaan Malaysia. 
12 and 176 of surah Al-Nisa. ${ }^{2}$

The translations of these verses are as follows: "Allah (thus) directs you as regards your children's inheritance: to the male, a portion equal to that of two females, if only daughters, two or more, their share is two-thirds of the inheritance; If only one, her share is a half. For parents, a sixth share of the inheritance to each, if the deceased left children; If no children, and the parents are the (only) heirs, the mother has a third; if the deceased left brothers (or sisters) the mother has a sixth. (The distribution in all cases is) after the payment of legacies and debts. You know not whether your parents or your children are nearest to you in benefit. These are settled portions ordained by Allah; and Allah is All-Knowing, All-Wise (Al-Nisa, 4: 11).

In that which your wives leave, your share is a half, if they leave no child; but if they leave a child, you get a fourth of that which they leave after payment of legacies that they may have bequeathed or debts. In that which you leave, their (your wives) share is a fourth if you leave no child; but if you leave a child, they get an eight of that which you leave after payment of legacies that you may have bequeathed or debts. If the man or woman whose inheritance is in question has left neither ascendants nor descendants, but has left a brother or a sister, each one of the two gets a sixth; but if more than two, they share in a third; after payment of legacies he (or she) may have bequeathed or debts, so that no loss is caused (to anyone). This is a commandment from Allah; and Allah is ever All-Knowing, Most Forbearing" (Al-Nisa, 4: 12).

They ask thee for a legal decision. Say: Allah directs (them) about those who leave no descendants or ascendants as heirs. If it is a man that dies, leaving a sister but no child, she shall have half the inheritance. If (such a deceased was) a woman who left no child, her brother takes her inheritance. If there are two sisters, they shall have two thirds of the inheritance (between them). If there are brothers and sisters, (they share), the male having twice the share of the female. Thus does Allah (swt) make clear to you (His law) let you go astray. And Allah is the All-knower of everything (Al-Nisa, 4: 176).

According to Islamic fiqh (jurisprudence), the one who has both male and female multiplicative organs is called a khuntha, or hermaphrodite. With regards to Islamic law, all actions will be taken to determine the gender of the hermaphrodite. Once the gender is determined, it will be treated as that gender for all legal rulings, including inheritance. ${ }^{3}$ Certain symbols essential to be analyzed to regulate the sex of the hermaphrodite, the first of which is the organ it uses to urinate. If it uses the male organ, he will be classified as a male; if it uses the female organ, she will be categorized as a female. If the hermaphrodite urinates from both the male and female organs, then the first one to release urine will determine the gender. These symbols should be analyzed at or immediately after birth to ascertain the sex of the hermaphrodite. ${ }^{4}$

${ }^{2}$ The Holy Quran, Suarh Al-Nisa verse 11, 12, 176.

${ }^{3}$ Ali, Amani, M. Ali, "Simplify inheritance rights in Islamic law Hermaphrodite right to inheritance and Married (khuntha)" Australian Journal of Basic and Applied Science, 10(7) Special 2016, p. 104-110.

${ }^{4}$ Ibid, p. 104. 
The hermaphrodite difficulty (khuntha mushkil) will be intended as a male and as a female in all inheritance scenarios. In whichever of the two cases it gets less inheritance, it will be treated as that gender and receive that share. This article shall also try to give an overview on the inheritance of hermaphrodite under the spirit of Quran with the help of Sunnah, Qiyas and different opinions of the Imam and jurists.

\section{Reports of Khuntha from Hadith (Sunnah)}

There are many references to these people, both directly and indirectly, Hadith and Sunnah. Two trustworthy Hadith are:

Narrated AbuHurayrah: A mukhannath who had dyed his hands and feet with henna was brought to the Prophet. He asked: What is the matter with this man? He was told: Apostle of Allah! He affects women's get-up. So ordered regarding him and he was banished to an-Naqi'. The people said: Apostle of Allah! Should we not kill him? He said: I have been prohibited from killing people who pray.

Abu Usamah said: Naqi' is a region near Medina and not a Baqi (in other words not referring to Jannat al-Baqi' cemetery. ${ }^{5}$

Narrated Aisha, Ummul Mu'minin:

A mukhannath (eunuch) used to enter upon the wives of Prophet. They (the people) counted him among those who were free of physical needs. One day the Prophet entered upon us when he was with one of his wives, and was describing the qualities of a woman, saying: When she comes forward, she comes forward with four (folds in her stomach), and when she goes backward, she goes backward with eight (folds in her stomach). The Prophet said: Do I not see that this (man) knows what here lies. Then they (the wives) observed veil from him. ${ }^{6}$

\section{Inheritance}

The precise meaning of inheritance is transferring an article from one person to another, usually this transfer denotes to wealth, knowledge, honor or dignity. According to Islamic law term, it refers to the transfer of moveable, immovable tangible and intangible properties belongings of the deceased to his/her living legal heirs.

\subsection{Basic Components of Inheritance}

There are three basic apparatuses of inheritance and they are:

a) Deceased: the person who died and left behind an estate or property.

b) Successors or heirs: those living individuals who are going to inherit the property of the deceased person.

c) Property or Assets: all moveable, immoveable tangible and intangible articles owned by deceased at the time of death. ${ }^{8}$

\footnotetext{
${ }^{5}$ An authentic Hadith narrated by Sunan Abu-Dawud, Book 41, Number 4910.

${ }^{6}$ An authentic Hadith narrated by Sunan Abu-Dawud, Book 32, Number 4095.

${ }^{7}$ Dr. Rehman, Tanzil-u, “Majmuah Qwanini Islam”, Islamic Research Institute, IIUI, $2^{\text {nd }}$ Edition, 1958, vol 5, p. 1585.

${ }^{8}$ Nasir bin Muhammad MishriAlghamidi, "Al-Khulasa-fi-ilm AL-faraid”, daar al-sidq Islamabad, maktabah Rashidiya Peshawar, p. 15-16.
} 


\section{The Concept of Hermaphrodite (Khuntha)}

Allah (S.W.T) has created three kinds of human beings in this world and those are male, female and hermaphrodite or khuntha. Gender grouping according to dimorphic classes is not new. In the terminology of medical science the hermaphrodite or khuntha is a person whose body does not confirm to arbitrarily quantified criteria for the male or female body and has confusing sex. ${ }^{9}$

The word hermaphrodite literally means doubled or doubling. The child born with male and female genital is called hermaphrodite. If hermaphrodite has male dominancy it would be considered as male and if hermaphrodite has female dominancy then it would be considered as female. An individual who stands a hermaphrodite has together female and male genital features and can also be called intersex persons. This usually means that the body part on the inside are of one sex, while the organs on the outside are of another sex; for instance, a hermaphrodite might have a penis and testicles, but inside, there are ovaries and probably a uterus. In additional infrequent cases, the chromosomes say a person is male or female, but the genitals say otherwise. ${ }^{10}$

\subsection{Hermaphrodite Difficulty}

When born, the only one test to identify the sex of that child is the female or male organ. But sometimes difficulty creates to determine that which sex is dominant in that child, so it would be considered as Hermaphrodite difficulty. The cause of this difficulty could be that the child has both male and female organs or organs may be absent in all or exist in such a form that creates ambiguity. ${ }^{11}$

Merely irregularly do hermaphrodites (Khuntha) actually indication the genitalia of both a male and a female; for illustration, a person might have a penis as well as a vagina. In several of these circumstances, the doctors aren't sure which genitalia the person has at birth: For instance, a female might appear to have a very large clitoris, or a male might appear to have a very small penis. These confusing genitalia often causes for further testing on DNA to determine whether the child is a boy or a girl. ${ }^{12}$

On the other hand, certain symbols need to be detected to determine the sex of the hermaphrodite. The first of which is the organ used to pass urine. If the person uses the male organ, he will be categorized as a male; if it uses the female organ, she will be categorized as a female. If the hermaphrodite urinates from both the male and female organs, then the first one to release urine will determine the gender. These signs should be observed at or immediately after. If these symbols were not analyzed as a new-born, the sex can still be ascertained later, when more signs appear. These are drawn below.

\subsubsection{Categorized as Male}

The Khuntha or hermaphrodite will be categorized as a male if any of the fol-

${ }^{9}$ Aziz, Abdul S, "Islamic Biomedical Ethics Principles and Application".

${ }^{10}$ Available at http://www.newhealthadvisor.com/hermaphrodite-human-pictures.html accessed in May 2017.

${ }^{11}$ Imran Ahsan K. Nayazee, “Outlines of Muslim Personal Law”, Federal Law House, Rawalpindi, Lahore.

${ }^{12}$ Ibid, f10. 
lowing happens:

a) He has sexual associations with his male reproductive organ.

b) His capabilities nocturnal discharge like men.

c) $\mathrm{He}$ is inclined to women.

d) He produces facial hair.

e) His testimony of his inner self.

\subsubsection{Categorized as Female}

The khuntha or hermaphrodite will be categorized as a female if any of the following happens:

a) She has sexual affairs with her female reproductive organ.

b) She becomes pregnant.

c) She practices menstruation.

d) She experiences the growth of breasts like women.

e) She lactates.

All these symbols should be observed out for when determining the gender of a hermaphrodite. If the hermaphrodite is categorized as a male, he will succeed to as a male in all cases. ${ }^{13}$ If the hermaphrodite is classified as a female, she will inherit as a female in all cases. Nevertheless, if nothing or all of these symbols happen then the hermaphrodite will not be assigned a gender. The person will be termed a hermaphrodite difficulty (khuntha mushkil).

\section{Inheritance of Hermaphrodite or Khuntha}

There is no identical and codified law for inheritance in Bangladesh but in Muslim Personal Law (shariat) Application Act 1937 a principal has been included and that is section 2 which says that:

"Notwithstanding any custom or usage to the contrary, in all questions (save questions relating to agricultural land) regarding intestate succession, special property of females, including personal property inherited or obtained under contract or gift or any other provision of personal law, marriage or dissolution of marriage, including talaq, ila, zihar, lian, Khula and mubaraat, maintenance, dower, guardianship, gifts, trusts and trust properties and waqfs (other than charitable institutions and charitable and religious endorsements) the rule of decision in cases where the parties are Muslims shall be the Muslim Personal Law (shariat)". ${ }^{14}$

Where the hermaphrodite is not difficult and it could be clearly determined that khuntha or hermaphrodite is to be deemed a male or female, the share of inheritance would be given to them according to their cases. All jurists are agreed upon that hermaphrodite will take share according to sex dominancy.

\subsection{Share of Hermaphrodite as a Male}

If hermaphrodite is considered as male then it would be considered as son,

${ }^{13}$ Mazumder Uddin, "Muslim Law of Inheritance and practice", Kitabtmohol, Dhaka, 2001, p. 100.

${ }^{14}$ The Muslim Personal Law (shariat) Application Act, 1937, sec. 2 (Act No. XXVI of 1937). 
brother, and paternal uncle. Two are more important and those are:

\subsubsection{Hermaphrodite OR Khuntha as a Son}

Sons share is doubled then daughter's share. So if khuntha considers as male and on the status of son it would get double share then daughter. As Allah S.W.T says in Quran:

"Man has double share than women". ${ }^{15}$

Table 1 shows that hermaphrodite considers as male and on the status of son would get double share then daughter.

If the deceased has one or more sons and no daughter than son or sons would be entitled to receive the entire estate equally.

\subsubsection{Hermaphrodite as a Brother}

If deceased's son, grandson how low so ever and grandfather how high so ever are not alive then brother would be entitled to receive the entire property left over from zawi-l-furud. ${ }^{16}$

Table 2 shows that hermaphrodite considers as brother and the deceased person has no son, grandson how low so ever and grandfather how high so ever are not alive then brother would be entitled to receive the entire property.

\subsection{Share of Hermaphrodite as a Female}

If hermaphrodite would be considers as female then it would take eminence of daughter, sister, and maternal aunt. Daughters and sisters are more important.

\subsubsection{Khuntha as a Daughter}

If the deceased has one daughter (khuntha) and has no son then $1 / 2$ share will be given to khuntha.

As instance, a woman dies leaving her father and daughter (hermaphrodite). Daughter (hermaphrodite) would get share in the following situation.

Table 3 shows that deceased has one daughter (Hermaphrodite) and has no son then $1 / 2$ share will be specified to Hermaphrodite.

If the deceased has sons and daughters (one is khuntha among them) both

Table 1. Share of hermaphrodite as son.

\begin{tabular}{cc}
\hline Heir & Share or portion \\
\hline Son (Hermaphrodite) & $\frac{2}{3}$ \\
Daughter & $\frac{1}{3}$ \\
\hline
\end{tabular}

Table 2. Hermaphrodite as brother.

\begin{tabular}{cc}
\hline \multicolumn{1}{c}{ Heir } & Portion or share \\
\hline Brother (Hermaphrodite) & $100 \%$ (whole property) \\
\hline \hline${ }^{15}$ The Holy Quran, Suarh Al-Nisa, verse 4: 11. \\
${ }^{16}$ Dr Tanzil-u-Rehman, “MajmuahQwanini Islam” Islamic Research Institute, IIUI, 2 ${ }^{\text {nd }}$ Edition, \\
1958, vol 5, p. 1778-1781.
\end{tabular}


Table 3. Hermaphrodites as daughter.

\begin{tabular}{cc}
\hline Heir & Share or portion \\
\hline Father & $\frac{1}{6}+$ Re siduary $=\frac{1}{2}$ \\
Daughter (Hermaphrodite) & $\frac{1}{2}$ \\
\hline
\end{tabular}

then the property shall be divided according to the general principle under which daughters share would be half to that of sons.

According to verse of Quran:

"Sons share is twice as compared to the share of daughter. If there are only daughters and no son, then they are all equally entitled to get $2 / 3$ of the share. But if there is only daughter and no son then she shall receive $1 / 2$ of the share in the inheritance". ${ }^{17}$

\subsubsection{Hermaphrodite (Khuntha) as a Sister}

Hermaphrodite as sister would get share in the following situations.

If a person died leaving no children, wife, brother, father and grandfather while has only one sister who is hermaphrodite (khuntha) then she would get $1 / 2$ share of the property in addition to if the deceased has more than one sister (one is khuntha among them) then $2 / 3$ of property would be divided equally among them.

On the other hand if the deceased has no children and his father has also died but he has one or more than one brothers and sisters (one is khuntha among them) the sisters get half of the brother's share.

According to verse of Holy Quran: "If the deceased has no children, father or mother but has one real sister or paternal sister she will get half of the share in the inheritance and he will also be the heirs of his sister. If his brother is dead and has no children, father or mother but has two or more sisters, then they will get to the extent of $2 / 3$ of the inheritance. But if the heirs include some brothers and sisters, then men will get double the share of women". ${ }^{18}$

If the deceased has no brother and his father and mother have also died but daughters and granddaughters are the only legal heirs alive then after deducting their shares, then the sister (khuntha) will get the remaining property. If son or grandson how low so ever of the deceased are alive then the sister (khuntha) would not be entitled to receive anything. ${ }^{19}$

\section{Inheritance of Hermaphrodite Difficulties}

Hermaphrodite who is not difficult, its inheritance is clear and determined but about inheritance of Hermaphrodite difficult, there is conflict between jurists. There are different opinions of jurists.

\footnotetext{
${ }^{17}$ The Holy Quran ,Suarh Al-Nisa, verse, 4: 11.

${ }^{18} \mathrm{Al}$ Quran Suarh Al-Nisa verse 17.

${ }^{19}$ Dr Tanzil-u-Rehman, "MajmuahQwanini Islam" Islamic Research Institute, IIUI, $2^{\text {nd }}$ Edition, 1958, vol 5, p. 1778-1781.
} 


\subsection{Opinions of Jurists}

According to Imam Abu Hanifa and Muhammad the general rule is that Hermaphrodite difficulties will take the share as female unless as a male he will get lesser share. In short lesser share would be given to Hermaphrodite difficulties.

For example:

If a person dies leaves son, daughter and hermaphrodite who is hermaphrodite difficulty. If hermaphrodite difficulty takes as daughter then:

Table 4 shows that in the case of hermaphrodite difficulties as daughter, here Son 2/4, daughter $1 / 4$ and hermaphrodite difficulty (khuntha Mushkil) daughter will get $1 / 4$ share of the deceased property.

And if a hermaphrodite difficulty takes as son then:

Table 5 illustrations that if hermaphrodite difficulties (Khuntha Mushkil) takes as son then: Son $2 / 4$, daughter $1 / 4$, hermaphrodite difficulties (Khuntha Mushkil) son 2/4.

So, $1 / 4$ is less than $2 / 4$ therefore hermaphrodite difficulties will take $1 / 4$ as daughter. This is also the common opinion of the companions of the Prophet P.B.U.H. ${ }^{20}$

In the view of Abu Yusuf and Al-Sha'bi hermaphrodite difficulties will get one-half share of the male and one-half share of female.

For example: hermaphrodite difficulties would take half of the certain share and half of the disputed share so that he would receive 3/4. Abu Yusuf pays attention to the share and applies the doctrine of increase and doctrine of Al-Sha'bi.

Table 4. Hermaphrodite difficulties as daughter.

\begin{tabular}{cc}
\hline Heir & Portion or share \\
\hline Son & $\frac{2}{4}$ \\
Daughter & $\frac{1}{4}$ \\
Hermaphrodite difficulty (daughter) & $\frac{1}{4}$ \\
\hline
\end{tabular}

Table 5. Hermaphrodite difficulties as son.

\begin{tabular}{cc}
\hline Heir & Portion or share \\
Son & $\frac{2}{4}$ \\
Daughter & $\frac{1}{4}$ \\
Hermaphrodite difficulties (son) & $\frac{2}{4}$
\end{tabular}

${ }^{20}$ AL-Haj M. Ullah, "The Muslim Law to Inheritance", university of Allahbad, Law publishing (company) p. 206-208. 


\subsection{Opinion of Majority Jurists and Preferred Opinion}

Majority of the jurists are in opinion of that hermaphrodite would get two shares, one share as male and one share as female. For example: If person leaves son, daughter and hermaphrodite, then hermaphrodite will take $3 / 4$ and it is equal to $1 / 2$ of the share of son plus half of the share of daughter that is $1 / 2+1 / 4=3 / 4$. This is also the preferred opinion. ${ }^{21}$

\section{Inheritance of Hermaphrodites in Contemporary Muslim World}

There is no conflict upon the inheritance of hermaphrodites in contemporary Muslim world and all jurists are agree upon that hermaphrodites will take share according to sex dominancy. If organs of male are prominent then it would be consider as male and if organs of female are present then it would be consider as female. But there is conflict on inheritance of khuntha mushkil (whose sex is ambiguous) that how much share it would inherit. There are different legislations in Contemporary Muslim world and these are as following.

\subsection{Law of Iran}

Section 939 of Family laws of Iran says that: If there is nothing in dominant in khuntha and it is difficult to determine its sex then one-half of the total shares of a boy (or a male member) and a girl (or a female member) of that category would be given to khuntha. It is similar to majority jurist's opinion. ${ }^{22}$

\subsection{Law of Egypt}

Inheritance law of Egypt describes the definition of khuntha mushkil and that is khuntha mushkil is that person about whom no one could determine that it's male or female. So Article 46 of Egyptian Laws of inheritance says: "The lesser share will be given to the khuntha mushkil" ${ }^{23}$ It means that if khuntha mushkil will get lesser share as female, then that share will be given and if it would get lesser share as male then that share would be given.

\subsection{Law of Syria}

Under the provision of Article 305 of the "Qanoon Al-Akhwal Al-Shakhsia" personal law of Syria adopted in their legislation about khuntha mushkil is "the lesser share would be given to khuntha mushkil". ${ }^{24}$

\subsection{Law of Iraq}

According to Article 188, the lesser share would be given to khunthamushkil because of sex ambiguity. Later on the rule was changed and that rule is based

${ }^{21}$ Nasir bin M.MishriAlghamidi, “Al-Khulasa-fi-ilm AL-faraid”, daar al-sidq Islamabad, maktabah Rashidiya Peshawar, p. 235.

${ }^{22}$ Dr Sayyid Ali Reza Naqavi, “Family Laws of Iran”, Islamic Research Institute 1971, p. 99.

${ }^{23}$ Dr Tanzil-u-Rehman, "MajmuahQwanini Islam”, Islamic Research Institute, IIUI, $2^{\text {nd }}$ Edition, 1958, vol 5, p. 1889

${ }^{24}$ The Qanoon al-akhwal al-shakhsia, Syria, Article 305. 
on opinion of majority jurists that is the hermaphrodite would get two shares, one share as male and one share as female. ${ }^{25}$

\subsection{Law of Kuwait}

Judicial Ministry of Kuwait has legislated in Article 334 that the smaller share would be given weather it takes as male or as female. It depends upon situation that how it takes lesser share. ${ }^{26}$

\subsection{Law of Yemen}

In Yemen, they have adopted opinion of Imam Malik. Article 332 of the Al-akhwal al-shakhsia states that Khuntha mushkil receive one-half of the total share of a boy (or a male member) and a girl (or a female member) of that category. ${ }^{27}$

\subsection{Law of Aljzair}

There is no codified law in Aljzair about khunthamushkil but Article 222 indicates that in state of conflict opinion of Imam Malik will prevail and Khunhamushkil would receive one-half as male and one-half as female. ${ }^{28}$

\subsection{Bangladesh}

There are no specific laws regarding the inheritance of hermaphrodites in Bangladesh. Islamic principles relating to inheritance of hermaphrodites also applicable in this country as per the followers of different imams.

\section{Contribution by This Research}

By This research, the hermaphrodite will be benefited if the property of their family will be distributed as shown above. Since there were no unique rules and guidelines for the distribution of their properties, this research shall play a vital role for the same.

The government of Islamic and non-Islamic states, legislature, and stakeholders shall be benefited by the outcome of this research. If the policymaker of the government drafts the laws for hermaphrodite accordingly, then the researcher, lawyers, and Judges will be able to make sure the rights of inheritance for the hermaphrodite.

\section{Scope of Further Research}

There are scopes for the following further research such as:

1) This research deals the provision of inheritance of a hermaphrodite under Muslim personal Laws only; so there are huge scopes for other researchers to research with the inheritance rights of hermaphrodite under Hindu, Christian, Buddhist and Jew's personal Laws.

2) There are also scopes for the researcher to do a comparative study among

\footnotetext{
${ }^{25}$ The Qanoon al-akhwal al-shakhsia 1959, Iraq, Artice 188.

${ }^{26}$ The Qanoon al-akhwal al-shakhsia, Kuwait, Part 8, Article 334, Ministry of Justice, 2011.

${ }^{27}$ The Qanoonal-akhwal al-shakhsia, Yemen, Article 332.

${ }^{28}$ TheQanoon-al-Usra,Aljzair, Article 222.
} 
the personal laws of Muslim Hindu, Christian, Buddhist and Jew.

\section{Conclusion}

Our social order is considerable far from the true essence of our religion Islam nowadays. Additionally very few from us follow the instructions of Islam. As we do not preserve hermaphrodites in our homes and don't give them their share of inheritance. We propel them in hijra communities to become burden for our society. Hermaphrodite who is not mushkil, its share of inheritance is much clear and determined, but not for the khunthamushkil (hermaphrodite difficulty).Therefore, in my unpretentious opinion hermaphrodites should be given two shares bestowing the opinion of majority jurists, one share as male and one share as female. So they can live better and become helpful part of our society not the burden. In addition to scientific research must take few steps more to get confirm that hermaphrodite difficulty (khunthamushkil) are considered as male or female. So its inheritance would be more clear and determined.

\section{References}

Al Quran Suarh Al-Nisa verse 17.

AL-Haj Mahomed Ullah, “The Muslim Law to Inheritance”, University of Allahbad, Law Publishing (Company), 206-208.

Ali, Amani, M. Ali (2016). Simplify Inheritance Rights in Islamic Law Hermaphrodite Right to Inheritance and Married (Khuntha). Australian Journal of Basic and Applied Science, 10, 104-110.

An authentic Hadith narrated by Sunan Abu-Dawud, Book 32, Number 4095.

An authentic Hadith narrated by suunan Abu-Dawud, Book 41,Number 4910.

Aziz, Abdul S. "Islamic Biomedical Ethics Principles and Application".

Dr. Rehman, Tanzil-u "MajmuahQwanini Islam”, Islamic Research Institute, IIUI, 2nd Edition, 1958, Vol. 5, 1585.

Dr. Sayyid Ali Reza Naqavi, “Family Laws of Iran”, Islamic Research Institute, 1971, 99.

Dr. Tanzil-u-Rehman "MajmuahQwanini Islam”, Islamic Research Institute, IIUI, 2nd Edition, 1958, Vol. 5, 1778-1781.

Dr. Tanzil-u-Rehman, "MajmuahQwanini Islam”, Islamic Research Institute, IIUI, 2nd Edition, 1958, Vol. 5, 1889.

Dr. Tanzil-u-Rehman, “MajmuahQwaniniIslam”, Islamic Research Institute, IIUI, 2nd Edition, 1958, Vol. 5, 1740-1741.

http://www.newhealthadvisor.com/hermaphrodite-human-pictures.html

Imran Ahsan Khan Nayazee "Outlines of Muslim Personal Law", Federal Law House, Rawalpindi, Lahore.

Mazumder Uddin (2001). Muslim Law of Inheritance and Practice (p. 100). Kitabtmohol, Dhaka.

Nasir bin Muhammad MishriAlghamidi, "Al-Khulasa-fi-ilm AL-faraid”, daar al-sidq Islamabad, maktabahRashidiyaPeshawar, 15-16.

Nasir bin Muhammad MishriAlghamidi, "Al-Khulasa-fi-ilm AL-faraid”, daar al-sidq Islamabad, maktabahRashidiyaPeshawar, 235.

Prof. Ridzuan M. Awang, "The Islamic Inheritance Law (Faraid), The Manifestation of Comprehensive Inheritance Management in Islam, Islamic Law (Shariah)”, Dept, Uni- 
versity Kabangsaan Malaysia.

The Holy Quran, Suarh Al-Nisa, Verse 11, 12, 176.

The Holy Quran, Suarh Al-Nisa, Verse 4: 11.

The Muslim Personal Law (Shariat) Application Act, 1937, sec. 2 (Act No. XXVI of 1937).

The Qanoon al-akhwal al-shakhsia 1959, Iraq, Article 188.

The Qanoon al-akhwal al-shakhsia, Kuwait, Part 8, Article 334, Ministry of Justice, 2011.

The Qanoon al-akhwal al-shakhsia, Syria, Article 305.

The Qanoon al-akhwal al-shakhsia, Yemen, Article 332.

The Qanoon-al-Usra, Aljzair, Article 222.

Submit or recommend next manuscript to SCIRP and we will provide best service for you:

Accepting pre-submission inquiries through Email, Facebook, LinkedIn, Twitter, etc. A wide selection of journals (inclusive of 9 subjects, more than 200 journals) Providing 24-hour high-quality service User-friendly online submission system Fair and swift peer-review system Efficient typesetting and proofreading procedure Display of the result of downloads and visits, as well as the number of cited articles Maximum dissemination of your research work

Submit your manuscript at: http://papersubmission.scirp.org/

Or contact blr@scirp.org 